\title{
The effect of the male contraceptive agent Gossypol on human lymphocytes in vitro: traditional chromosome breakage, micronuclei, sister chromatid exchange, and cell kinetics*
}

\author{
YING-CHI TSUI $\dagger$, MICHAEL R CREASY $\ddagger$, AND MAJ A HULTÉN \\ From $\dagger$ the National Research Institute for Family Planning, Chinese Academy of Medical Sciences, \\ Peking, China; and $\ddagger$ the West Midlands Regional Cytogenetics Laboratory, East Birmingham Hospital, \\ Birmingham.
}

SUMMARY The male antifertility agent Gossypol did not affect the level of traditional chromosome breakage or number of micronuclei in 66-hour lymphocyte cultures at concentrations up to $40 \mu \mathrm{g} / \mathrm{ml}$. It did increase the frequency of SCE slightly, although the inter-individual variation was greater than the increase resulting from Gossypol, and, even at the highest concentration $(40 \mu \mathrm{g} / \mathrm{ml})$, the SCE rate was still within the normal range. It also affected cell kinetics, reducing the mitotic index and the proportion of second and third metaphases after BUdR incorporation.

Oral contraceptives are popular because of their reliability and ease of use. The oral contraceptives currently available in the western world are only for female use and have side effects and health risks which make them unsuitable for many women. A male oral contraceptive would hopefully have the same advantages as 'the pill' and would, at least, enable couples to distribute the hazards of oral contraception more equitably between the sexes.

In the late 1950s it was noticed that fecundity was much lower in the Habeth province of China, where cotton seed oil was the main dietary fat, than in other areas. Subsequent research revealed that a yellow, lipid-soluble, phenolic extract of cotton seed oil, called Gossypol, was an effective male contraceptive, inhibiting spermatogenesis. Clinical trials were begun in China in 1972, since which time more than 10000 healthy males have taken Gossypol. They were initially given a daily dose of $20 \mathrm{mg}$ of Gossypol formate or Gossypol acetate orally for 2 months until azoospermia or extreme oligospermia was induced. A subsequent monthly maintenance dose of 150 to $220 \mathrm{mg}$ kept the sperm count below 4 million $/ \mathrm{ml}$ in $98.99 \%$ of the men. This experience is summarised in the report of the National Coordinating Group on Male Antifertility

* This work was carried out at the East Birmingham Hospital while Dr Tsui was in receipt of a travel grant from the World Health Organization.

Received for publication 23 September 1982.
Agents (China) ${ }^{12}$ and by Wen. ${ }^{3}$ The clinical side effects of Gossypol appear to be mild and infrequent, although hypokalaemic paralysis was encountered in one area. ${ }^{4}$

Its exact mode of action is unknown, but it does not alter the serum levels of luteinising hormone or testosterone in the rat or of follicle stimulating hormone in the pig. Its potency as a suppressor of spermatogenesis varies in different mammalian species, no effect being seen in the rabbit with daily doses of $10 \mathrm{mg} / \mathrm{kg}^{5}{ }^{5}$ In the rat the seminiferous tubules become depopulated and atrophic, until they contain only Sertoli cells and spermatogonia, while the testicular interstitial cells are not affected. Sperm count returns to normal after cessation of treatment.

It is not mutagenic in the Ames Salmonellamicrosome test, ${ }^{6}$ and limited investigations have failed to demonstrate any damage to chromosomes of lymphocytes in vivo. ${ }^{12}$ In this paper we report the effects of Gossypol in vitro on levels of chromosome damage, micronucleus formation, and sister chromatid exchange, and on the cell kinetics of human lymphocytes.

\section{Materials and methods}

CHROMOSOME BREAKAGE AND MICRONUCLEI Blood from five male volunteers, aged $22,25,27,50$, and 51 years was used to set up 66-hour lymphocyte 
cultures according to the method of Moorhead et al. ${ }^{7}$ Gossypol from a fresh stock solution $(8 \mathrm{mg}$ in $0.2 \mathrm{ml}$ dimethyl sulphoxide to $19.8 \mathrm{ml}$ TC 199 medium) was added to these at the start of culture, at final concentrations of $4,20,30$, and $40 \mu \mathrm{g} / \mathrm{ml}$. The concentration of $4 \mu \mathrm{g} / \mathrm{ml}$ was believed to correspond approximately to the mean level in the blood of Gossypol users. A control culture was treated identically but without the addition of Gossypol. Air dried slides from these cultures were stained with Giemsa for analysis of traditional chromosome breakage and micronuclei. Traditional chromosome breakage was evaluated by analysis of 100 metaphase cells from these cultures and another 100 first metaphase cells of the BUdR cultures (see below). Aberrations and micronuclei were scored according to the criteria of Evans and O'Riordan ${ }^{8}$ and Countryman et al, ${ }^{9}$ respectively.

\section{SISTER CHROMATID EXCHANGE}

In order to investigate sister chromatid exchange (SCE) another culture from each subject was

TABLE 1 Number of cells scored.

\begin{tabular}{llllll}
\hline $\begin{array}{l}\text { Concen- } \\
\text { tration of }\end{array}$ & \multicolumn{2}{l}{ No of cells scored } & & Total \\
\cline { 2 - 5 } $\begin{array}{l}\text { Gossypol } \\
\mu \mathrm{g} / \mathrm{ml})\end{array}$ & $\begin{array}{l}\text { For } \\
\text { mitotic } \\
\text { index }\end{array}$ & $\begin{array}{l}\text { For } \\
\text { micro- } \\
\text { nuclei }\end{array}$ & $\begin{array}{l}\text { For chromo- } \\
\text { some } \\
\text { aberrations }\end{array}$ & $\begin{array}{l}\text { For } \\
\text { SCE }\end{array}$ & \\
\hline 0 & 18000 & 7000 & 1000 & 500 & 26500 \\
4 & 10000 & 5000 & 1000 & 500 & 16500 \\
20 & 10000 & 5000 & 1000 & 500 & 16500 \\
30 & 10000 & 5000 & 1000 & 500 & 16500 \\
40 & 18000 & 5000 & 1000 & 351 & 24351 \\
Total & 66000 & 27000 & 5000 & 2351 & 100351 \\
\hline
\end{tabular}

processed as above, with the addition of 5bromodeoxyuridine (BUdR) at a final concentration of $30 \mu \mathrm{g} / \mathrm{ml} .^{10}$ One 66-hour culture with $30 \mathrm{ng} / \mathrm{ml}$ and one with $50 \mathrm{ng} / \mathrm{ml}$ of mitomycin C were also set up as positive controls. Slides were stained by the FPG method of Perry and Wolff11 and the level of SCE was analysed in 100 cells at second metaphase excluding 'centromeric exchanges'. ${ }^{12}$

\section{CELL KINETICS}

The effect of phytohaemagglutinin (PHA) on lymphocytes was judged by scoring the number of large 'stimulated' interphase nuclei in 1000 interphase cells (500 each from two slides) at each dose for each subject. Mitotic index was estimated as the number of cells in division among 1000 nuclei, again 500 each from two slides.

Two series of cultures containing $30 \mu \mathrm{g} / \mathrm{ml} \mathrm{BUdR}$ were set up with blood from two further men, aged 28 and 35 years. Gossypol was added to one of these series at a final concentration of $40 \mu \mathrm{g} / \mathrm{ml}$. Pairs of cultures, with and without Gossypol, were harvested after 48, 66, 72, and 96 hours. Two further series of control cultures, without Gossypol, were set up containing $0.06 \mathrm{ml}$ and $0.6 \mathrm{ml}$ of a $1 \%$ dimethyl sulphoxide (DMSO) solution, corresponding to the DMSO dose of the 4 and $40 \mu \mathrm{g} / \mathrm{ml}$ test cultures. No difference was found between the two doses of DMSO, and therefore the data have been pooled as 'O Gossypol cultures' in the tables.

\section{Results}

The number of cells scored for the different procedures is shown in table 1 .

TABLE 2 Chromosome aberrations.

\begin{tabular}{|c|c|c|c|c|c|c|c|c|c|c|}
\hline \multirow{2}{*}{$\begin{array}{l}\text { Concentra- } \\
\text { tion of } \\
\text { Gossypol } \\
(\mu g / m l)\end{array}$} & \multicolumn{3}{|c|}{ In conventionally stained lymphocytes } & \multicolumn{3}{|c|}{ In first division metaphases } & \multicolumn{4}{|l|}{ Total } \\
\hline & $\begin{array}{l}\text { No of } \\
\text { spreads }\end{array}$ & $\begin{array}{l}\text { No of cells } \\
\text { with } \\
\text { aberrations }\end{array}$ & $\begin{array}{l}\text { No of } \\
\text { chromosome } \\
\text { aberrations }\end{array}$ & $\begin{array}{l}\text { No of } \\
\text { spreads }\end{array}$ & $\begin{array}{l}\text { No of cells } \\
\text { with } \\
\text { aberrations }\end{array}$ & $\begin{array}{l}\text { No of } \\
\text { chromosome } \\
\text { aberrations }\end{array}$ & $\begin{array}{l}\text { No of } \\
\text { spreads }\end{array}$ & $\begin{array}{l}\text { No of cells } \\
\text { with } \\
\text { aberrations }\end{array}$ & $\begin{array}{l}\text { No } \\
\text { chro } \\
\text { aber }\end{array}$ & $\begin{array}{l}\text { of } \\
\text { omosome } \\
\text { rrations }\end{array}$ \\
\hline $\begin{array}{l}0 \\
4 \\
20 \\
30 \\
40 \\
\text { Total }\end{array}$ & $\begin{array}{r}500 \\
500 \\
500 \\
500 \\
500 \\
2500\end{array}$ & $\left.\begin{array}{l}8 \\
6 \\
8 \\
5 \\
4\end{array}\right\}_{31}^{23} 1 \cdot 2 \%$ & $\left.\begin{array}{l}8 \\
6 \\
8 \\
5 \\
4\end{array}\right\}_{31}^{23} 1 \cdot 2 \%$ & $\begin{array}{r}500 \\
500 \\
500 \\
500 \\
500 \\
2500\end{array}$ & $\left.\begin{array}{l}1 \\
3 \\
1 \\
3 \\
3\end{array}\right\} \begin{array}{c}10 \\
0.5 \% \\
11\end{array}$ & $\left.\begin{array}{l}1 \\
9 \\
3 \\
3 \\
3\end{array}\right\}_{19}^{18} 0.9 \%$ & $\begin{array}{l}1000 \\
1000 \\
1000 \\
1000 \\
1000 \\
5000\end{array}$ & $\left.\begin{array}{l}9 \\
9 \\
9 \\
8 \\
7\end{array}\right\} \begin{array}{c}0.9 \% \\
35 \\
42\end{array}$ & $\left.\begin{array}{r}9 \\
15 \\
11 \\
8 \\
7\end{array}\right\}$ & $\begin{array}{l}0.9 \% \\
41 \\
1.03 \% \\
50\end{array}$ \\
\hline
\end{tabular}

TABLE 3 Types of chromosome aberrations.

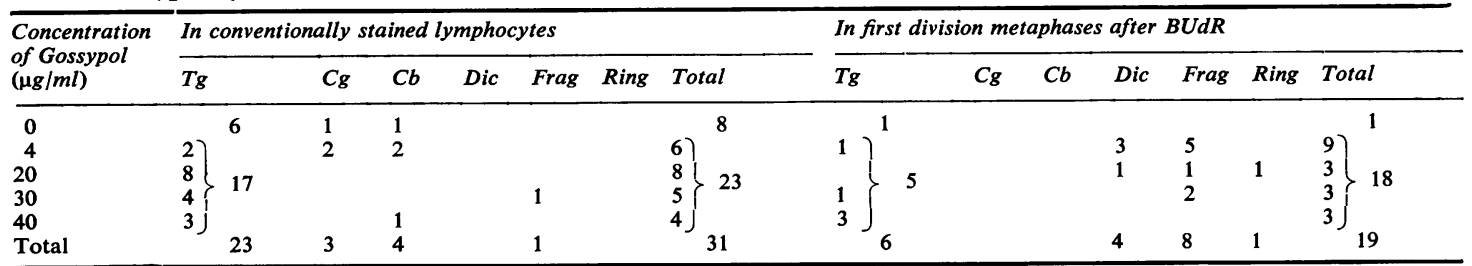

$\mathrm{Tg}$, chromatid gap; $\mathrm{Cg}$, chromosome gap; $\mathrm{Cb}$, chromosome break; Dic, dicentric; Frag, fragment. 
TRADITIONAL CHROMOSOME ABERRATIONS The frequency and types of chromosome abnormalities detected by conventional analysis are given in tables 2 and 3.

After Gossypol treatment, $1 \cdot 2 \%$ of cells (23/2000) had a chromosome aberration, compared to $1.6 \%$ $(8 / 500)$ of control cultures (table 2$)$. This difference is not statistically significant. No cell contained more than one aberration.

First metaphases of BUdR cultures generally had a lower frequency of aberrations than conventional cultures, as noted previously. ${ }^{13}$ In the Gossypol cultures $0.5 \%$ of cells $(10 / 2000)$ had one or more chromosome aberrations compared to $0.2 \%$ of cells $(1 / 5000)$ in control cultures. Again, the difference is not significant, neither is there any statistically significant difference in the total number of aberrations.

The aberrations observed were mostly chromatid gaps (table 3 ). One cell in the $4 \mu \mathrm{g} / \mathrm{ml}$ cultures had three dicentrics and four acentric fragments, while one cell in the $20 \mu \mathrm{g} / \mathrm{ml}$ cultures had one dicentric, one ring chromosome, and one acentric fragment.

\section{MICRONUCLEI}

The results of the micronucleus analysis are shown in table 4. The control cultures without Gossypol contained 2.8 micronuclei per 1000 cells. None of the four doses of Gossypol produced a statistically significant increase in the number of micronuclei. Although there was an increase in the number of micronuclei with increasing dosage of Gossypol, the lower values were below that of the control so it is difficult to attach any significance to this apparent trend. All the values were within the normal range. ${ }^{9}$

Only one cell had more than a single micronucleus. This cell, from the $40 \mu \mathrm{g} / \mathrm{ml}$ concentration of Gossypol, had two.

The cultures treated with mitomycin $\mathrm{C}$ showed a clear increase in the number of micronuclei.

SISTER CHROMATID EXCHANGE

The level of SCE increased with dose of Gossypol

TABLE 4 Frequency of micronuclei in Gossypol treated cultures compared with untreated and mitomycin $C$ treated cultures.

\begin{tabular}{|c|c|c|c|}
\hline Treatment & $\begin{array}{l}\text { No of cells } \\
\text { scored }\end{array}$ & $\begin{array}{l}\text { No of } \\
\text { micronuclei }\end{array}$ & $\%$ \\
\hline $\begin{array}{l}\text { Control } \\
\quad \text { (untreated) }\end{array}$ & 5000 & 14 & 0.28 \\
\hline \multicolumn{4}{|l|}{ Gossypol } \\
\hline $4 \mu \mathrm{g} / \mathrm{ml}$ & 5000 & $10)$ & \\
\hline $20 \mu \mathrm{g} / \mathrm{ml}$ & 5000 & $1 3 \longdiv { 5 4 }$ & 0.27 \\
\hline $30 \mu \mathrm{g} / \mathrm{ml}$ & 5000 & $15\}^{54}$ & \\
\hline $40 \mu \mathrm{g} / \mathrm{ml}$ & 5000 & $16)$ & \\
\hline \multicolumn{4}{|l|}{ Mitomycin C } \\
\hline $30 \mathrm{ng} / \mathrm{ml}$ & 1000 & 36 & $3 \cdot 60$ \\
\hline $50 \mathrm{ng} / \mathrm{ml}$ & 1000 & 60 & 6.00 \\
\hline
\end{tabular}

TABLE 5 Effect of Gossypol on the frequency of sister chromatid exchange in lymphocytes of different subjects.

\begin{tabular}{|c|c|c|c|c|c|c|c|c|}
\hline \multirow{3}{*}{$\begin{array}{l}\text { Concen- } \\
\text { tration } \\
\text { of } \\
\text { Gossypol } \\
(\mu \mathrm{g} / \mathrm{ml})\end{array}$} & \multicolumn{7}{|c|}{ Mean no of SCEs per cell } & \multirow[t]{3}{*}{ Range } \\
\hline & \multicolumn{5}{|c|}{ Subjects } & \multirow{2}{*}{ Total } & \multirow{2}{*}{$\begin{array}{c}\text { Standard } \\
\text { deviation }\end{array}$} & \\
\hline & $I$ & $I I$ & $I I I$ & $I V$ & $V$ & & & \\
\hline $\begin{array}{r}0 \\
4 \\
20 \\
30 \\
40\end{array}$ & $\begin{array}{l}6 \cdot 83 \\
6 \cdot 40 \\
6 \cdot 75 \\
7 \cdot 15 \\
5 \cdot 42^{*}\end{array}$ & $\begin{array}{l}5 \cdot 83 \\
6 \cdot 33 \\
7 \cdot 19 \\
7 \cdot 15 \\
7 \cdot 20\end{array}$ & $\begin{array}{l}7 \cdot 17 \\
7 \cdot 20 \\
7 \cdot 88 \\
7 \cdot 92 \\
9 \cdot 07\end{array}$ & $\begin{array}{l}10 \cdot 19 \\
10 \cdot 52 \\
10 \cdot 77 \\
11 \cdot 04 \\
11 \cdot 96+\end{array}$ & $\begin{array}{l}6 \cdot 74 \\
6 \cdot 71 \\
6 \cdot 99 \\
6 \cdot 94 \\
6 \cdot 87\end{array}$ & $\begin{array}{l}7 \cdot 35 \\
7 \cdot 42 \\
7 \cdot 92 \\
8 \cdot 04 \\
8 \cdot 10\end{array}$ & $\begin{array}{l}3.40 \\
3.51 \\
3.62 \\
3.49 \\
3.46\end{array}$ & $\begin{array}{l}1-19 \\
0-24 \\
1-27 \\
1-21 \\
2-21\end{array}$ \\
\hline
\end{tabular}

100 cells scored at each dosage for each subject except $7^{*}$ cells and $44+$ cells.

(table 5). The individual values for the five men showed that each of them responded in a similar way, but that the inter-individual variation was much greater than the Gossypol induced increase. Analysis of variance showed that the inter-individual variation is highly significant $(\mathrm{p}<<0.005)$, as is the variation owing to dosage $(p<0.005)$. Although much of the inter-individual variation is due to one subject, excluding him did not alter the levels of significance greatly. Even at the highest dose of Gossypol, the increase in the level of SCE above the control level was not very great.

\section{CELL KINETICS}

Table 6 shows that the response of lymphocytes to PHA decreased with increasing Gossypol concentration. The proportion of large stimulated nuclei decreased from $59.1 \%$ of interphase nuclei in control cultures to $30.5 \%$ at the highest dose of Gossypol. Similarly, the mitotic index decreased from $7 \cdot 12 \%$ without Gossypol to $3 \cdot 24 \%$ at $40 \mu \mathrm{g} / \mathrm{ml}$ Gossypol in conventional cultures. In the BUdR treated cultures the corresponding decrease was from $5.82 \%$ to $2.84 \%$. In both cases Gossypol decreases the mitotic index by $0.07 \%$ for each additional $\mu \mathrm{g} / \mathrm{ml}$ (table 6). Both of these findings suggest that Gossypol reduces, or retards, the response of lymphocytes to PHA stimulation.

Table 7 and fig 1 show that increasing concentrations of Gossypol increased the proportion

TABLE 6 The effect of Gossypol on mitotic index and stimulation by $\mathrm{PHA}$.

\begin{tabular}{|c|c|c|c|}
\hline \multirow{2}{*}{$\begin{array}{l}\text { Concentration } \\
\text { of Gossypol } \\
(\mu \mathrm{g} / \mathrm{ml})\end{array}$} & \multirow{2}{*}{$\begin{array}{l}\% \text { interphase } \\
\text { cells stimulated } \\
\text { by } P H A\end{array}$} & \multicolumn{2}{|c|}{ Mitotic index $(\%)$} \\
\hline & & $\begin{array}{l}\text { In conventional } \\
\text { cultures }\end{array}$ & $\begin{array}{l}\text { In BUdR treated } \\
\text { cultures }\end{array}$ \\
\hline $\begin{array}{r}0 \\
4 \\
20 \\
30 \\
40\end{array}$ & $\begin{array}{l}59 \cdot 1 \\
53 \cdot 7 \\
43 \cdot 5 \\
40 \cdot 1 \\
30 \cdot 5\end{array}$ & $\begin{array}{l}7 \cdot 12 \\
6 \cdot 08 \\
6 \cdot 70 \\
5 \cdot 54 \\
3 \cdot 24\end{array}$ & $\begin{array}{l}5 \cdot 82 \\
5 \cdot 22 \\
4 \cdot 72 \\
3 \cdot 60 \\
2 \cdot 84\end{array}$ \\
\hline
\end{tabular}


of first division metaphases while decreasing the proportion of metaphases in their third division after 66 hours of culture with BUdR. Table 8 and fig 2 show how the proportion of second and third division metaphases increased more slowly in

TABLE 7 Proportion of first, second, and third metaphases after 66 hours culture with BUdR and different concentrations of Gossypol.

\begin{tabular}{|c|c|c|c|c|}
\hline \multirow{2}{*}{$\begin{array}{l}\text { Concentra- } \\
\text { tion of } \\
\text { Gossypol } \\
(\mu \mathrm{g} / \mathrm{ml})\end{array}$} & \multicolumn{3}{|c|}{ No and $\%$ of metaphases } & \multirow[t]{2}{*}{ Total } \\
\hline & $\begin{array}{l}\text { First } \\
\text { metaphases }\end{array}$ & $\begin{array}{l}\text { Second } \\
\text { metaphases }\end{array}$ & $\begin{array}{l}\text { Third } \\
\text { metaphases }\end{array}$ & \\
\hline 0 & $\begin{array}{l}108 \\
(37 \cdot 11 \%)\end{array}$ & $\begin{array}{l}130 \\
(44.68 \%)\end{array}$ & $53(18 \cdot 12 \%)$ & 291 \\
\hline 4 & $\begin{array}{l}114 \\
(43.68 \%)\end{array}$ & 115 & ${ }^{32}(12 \cdot 26 \%)$ & $\begin{array}{l}261 \\
(100 \%)\end{array}$ \\
\hline 20 & $\begin{array}{l}113 \\
(47 \cdot 88 \%)\end{array}$ & $\begin{array}{l}102 \\
(43 \cdot 22 \%)\end{array}$ & $21 \quad(8.90 \%)$ & $236(100 \%)$ \\
\hline 30 & 102 & $\begin{array}{l}65 \\
(36 \cdot 11 \%)\end{array}$ & $13(7.22 \%)$ & $\begin{array}{l}180 \\
(100 \%)\end{array}$ \\
\hline 40 & $\begin{array}{l}90 \\
(63.38 \%)\end{array}$ & $44(30.99 \%)$ & 8 (5.63\%) & $\begin{array}{l}142 \\
(100 \%)\end{array}$ \\
\hline
\end{tabular}

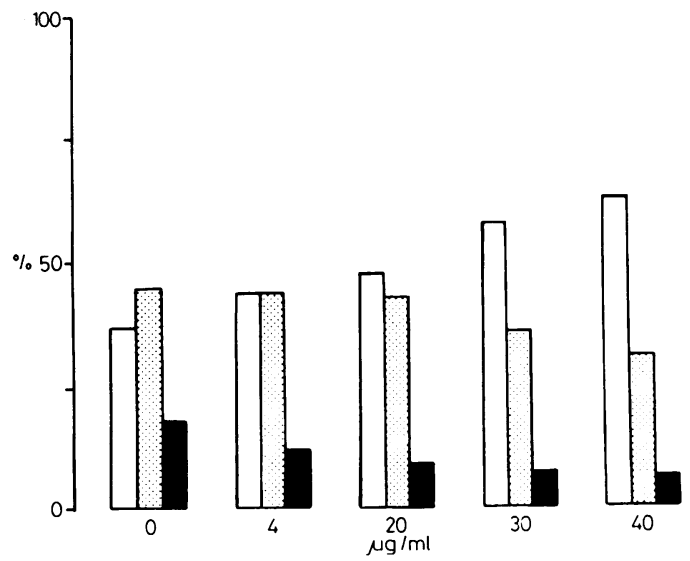

FIG 1 Proportion of first (white blocks), second (shaded blocks), and third (black blocks) metaphases after 66 hours of culture with BUdR and various concentrations of Gossypol.

TABLE 8 Proportion of first, second, and third and further mitoses in lymphocyte cultures treated with Gossypol $(40 \mu \mathrm{g} / \mathrm{ml})$ for different culture times. Values of control cultures are given in brackets.

\begin{tabular}{llcl}
\hline $\begin{array}{l}\text { Culture time } \\
(h)\end{array}$ & $\begin{array}{l}\text { First } \\
\text { mitoses }\end{array}$ & $\begin{array}{l}\text { Second } \\
\text { mitoses }\end{array}$ & $\begin{array}{l}\text { Third and } \\
\text { further mitoses }\end{array}$ \\
\hline 48 & $100(100)$ & $0(0)$ & $0(0)$ \\
66 & $84(55)$ & $16(44)$ & $0(1)$ \\
72 & $83(27)$ & $17(58)$ & $0(15)$ \\
96 & $67(16)$ & $33(35)$ & $0(49)$ \\
\hline
\end{tabular}
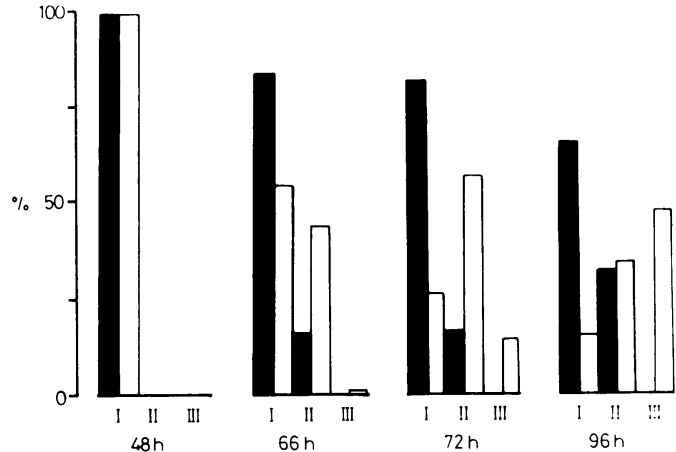

FIG 2 Proportion of metaphases at first $(I)$, second (II), and third (III) division after BUdR incorporation. Black blocks $=40 \mu \mathrm{g} / \mathrm{ml}$ Gossypol, white blocks $=$ without Gossypol.

cultures containing $40 \mu \mathrm{g} / \mathrm{ml}$ Gossypol than in controls. Indeed, in this experiment, no third division metaphases were seen after 96 hours of culture with $40 \mu \mathrm{g} / \mathrm{ml}$ Gossypol. This is in contrast to the previous experiment in which $5.3 \%$ of the metaphases were in their third division after only 66 hours of culture. This serves to emphasise the large variation in individual response to Gossypol.

\section{Discussion}

At the concentrations tested, Gossypol appears to have very little adverse effect on lymphocyte chromosomes in vitro. No increase in the level of chromosome or chromatid aberrations was detected by either direct analysis or micronuclei. There was a slight increase in the frequency of sister chromatid exchange, but even at the highest doses the level was still within the normal range. Gossypol does retard the kinetics of lymphocyte response to PHA.

In conventionally stained preparations there was no difference in the frequency of chromatid or chromosome aberrations between Gossypol treated cultures $(1.6 \%)$ and controls $(1.2 \%)$. In the cells in their first metaphase after BUdR treatment the o level of chromosome aberrations was higher in $N$ Gossypol cultures $(0.9 \%)$ than controls $(0.2 \%)$ but the difference was not statistically significant $(p<0 \cdot 1)$. The increase was largely the result of two cells, one of which had three dicentrics and four acentrics $(4 \mu \mathrm{g} / \mathrm{ml}$ Gossypol), while the other had $\&$ one dicentric, one ring, and one acentric $(20 \mu \mathrm{g} / \mathrm{ml}$ Gossypol). There was no increase in aberrations with Gossypol concentration.

The micronucleus test provides a quick and simple way of scoring large numbers of cells for certain chromosome aberrations. It has been shown to be a 
sensitive test for detecting radiation induced chromosome damage in human lymphocytes. ${ }^{13}$ In this study, the micronucleus test results were in agreement with the analysis of chromosome aberrations. The incidence of micronuclei was the same in the Gossypol treated $(0.27 \%)$ and untreated $(0.28 \%)$ cultures. There was, however, a suggestion of a very slight dose dependent increase in micronuclei, from $0.2 \%$ at $4 \mu \mathrm{g} / \mathrm{ml}$ Gossypol to $0.32 \%$ at $40 \mu \mathrm{g} / \mathrm{ml}$, but the values at the lower concentrations were below the control levels, so it is difficult to interpret this trend as real.

The level of sister chromatid exchange showed a slight dose dependent increase in Gossypol treated cultures. This effect was present in all five subjects tested. However, the untreated SCE rate for one subject was higher than the rate at the highest concentration of Gossypol in all other subjects. Even at the highest concentrations used, which were believed to be ten times the serum level in users, the SCE rate was not outside the normal range which, for man, is about one to 12 exchanges per metaphase..$^{12} \mathrm{It}$ is thus difficult to know if these findings have any clinical significance. We had no clinical details of the donors which might be relevant to their SCE level, for example, their smoking habits. ${ }^{14}$ Because of this finding an investigation of the in vivo SCE levels of Gossypol users is being undertaken.

Gossypol does produce a definite effect upon lymphocyte kinetics following PHA stimulation. This can be clearly seen from the reduction in mitotic index, the decrease in the proportion of stimulated interphase nuclei, and the dose dependent decrease in second and third metaphases after BUdR treatment in 66-hour cultures, as well as the progressive reduction in second and third metaphases after BUdR treatment for between 66 and 96 hours. This effect of Gossypol may be similar to its effect upon the germinal epithelium in suppressing spermatogenesis. It is known from experimental work with the rat that Gossypol does not accumulate preferentially in the testis ${ }^{12}$ and hence germ cells are presumably more sensitive to its action than other cells.

Gossypol is potentially a very useful antifertility agent which is not currently available outside the People's Republic of China. Research undertaken to date does not suggest that it has any adverse mutagenic, oncogenic, or clastogenic effects. It does not appear to damage lymphocyte chromosomes, although it does not necessarily follow that this is true of spermatogonial chromosomes. It is hoped that this can be checked in China using the technique of Rudak et al..$^{15}$ The effects on sister chromatid exchange and cell kinetics are difficult to evaluate. Because of the large variation in response between subjects it would be desirable to extend the number of persons examined in this present study. The significance of very small increases in the frequency of sister chromatid exchange is not clear and will only be fully appreciated when more substances have been tested in this way.

We are grateful to the Xi-an Oil Chemical Factory for the generous gift of the Gossypol, to Dr A M R Taylor for advice with experimental technique, and to Dr D A Laurie for help with the statistical analysis. The work was supported by the World Health Organization.

\section{References}

1 National Coordinating Group on Male Antifertility Agents (China). Gossypol-a new antifertility agent for males. Chin Med J 1978;4:417-8.

2 National Coordinating Group on Male Antifertility Agents (China). Gossypol-a new antifertility agent for males. Gynecol Obstet Invest 1979;10:163-76.

3 Wen W. China invents male birth control pill. Am J Chin Med 1980;3:195-7.

${ }^{4}$ Qian S, Jing G, Wu X, Xu Y, Li Y, Zhou Z. Gossypol related hypokalemia. Chin Med J 19S3;2j:477-82.

5 Chang MC, Gu Z, Saksena SK. Effects of Gossypol on the fertility of male rats, hamsters and rabbits. Contraception $1980 ; 8: 461-9$.

6 De Peyster A, Wang YY. Gossypol-proposed contraceptive for men passes the Ames test. $N$ Engl J Med 1979; $301: 275-6$.

7 Moorhead PS, Nowell PC, Mellman WJ, Battips DM, Hungerford DA. Chromosome preparations of leukocytes cultured from human peripheral blood. Exp Cell Res 1960;20:613-6.

${ }^{8}$ Evans HJ, O'Riordan ML. Human peripheral blood lymphocytes for the analysis of chromosome aberrations in mutagen tests. Mutat Res $1975 ; 31: 135-48$.

9 Countryman PI, Heddle JA. The production of micronuclei from chromosome aberrations in irradiated cultures of human lymphocytes. Mutat Res 1976;41: 321-2.

${ }^{10}$ Latt SA. Sister chromatid exchanges, indices of human chromosome damage and repair: detection by fluorescence and induction by mitomycin C. Proc Natl Acad Sci USA 1974;71:3162-6.

11 Perry P, Wolff S. New Giemsa method for the differential staining of sister chromatids. Nature 1974 ;251 :156-8.

12 Beek B, Obe G. Sister chromatid exchanges in human leukocyte chromosomes: spontaneous and induced frequencies in early- and late-proliferating cells in vitro. Hum Genet 1979;49:51-61.

13 Gebhart E, Windolph B, Wopfner F. Chromosome studies on lymphocytes of patients under cytostatic therapy. Hum Genet 1980;56:157-67.

14 Lambert B, Lindblad A, Nordenskjold M, Werelius B. Increased frequency of sister chromatid exchanges in cigarette smokers. Hereditas 1978;88:147-9.

15 Rudak E, Jacobs PA, Yanagimachi R. Direct analysis of the chromosome constitution of human spermatozoa. Nature 1978;274:911-3.

Requests for reprints to Dr M R Creasy, Regional Cytogenetics Laboratory, East Birmingham Hospital, Bordesley Green East, Birmingham B9 5ST. 